\title{
Morphometric Indices in Santa Ines Sheep
}

\author{
Índices Morfométricos en Ovejas Santa Ines
}

\begin{abstract}
Ricardo Lopes Dias da Costa*; Celia Raquel Quirino**; Vivian Alves Costa Afonso***; Aline Pacheco**; Renato Travassos Beltrame $^{* * * * *}$; Aparecida de Fátima Madella-Oliveira ${ }^{* * * * * *}$; Aline Mineiro Costa** \& Roberto Machado Carneiro da Silva ${ }^{* * *}$
\end{abstract}

DA COSTA, R. L. D.; QUIRINO, C. R.; ALFONSO, V. A. C.; PACHECO, A.; BELTRAME, R. T.; MADELLA-OLIVEIRA, A. F.; COSTA, A. M. \& DA SILVA, R. M. C. Morphometric indices in Santa Ines sheep. Int. J. Morphol., 32(4):1370-1376, 2014.

SUMMARY: The aim of this study was to evaluate the effect of period of the year, year of the birth, sex and age on morphometric indices, such as body capacity, body indices, body side indice, anamorphosis indice, compactness indice and body proportionality indice. The correlation between these characteristics was calculated. Santa Ines sheep offspring from the birth to 12 months-old, at the Estado do Rio de Janeiro were used. Measurements were obtained from animals under an extensive scheme within three years of study totaling 2,601 observations. In this work, the year of birth, sex, animal age and triple interaction between these effects have influenced $(\mathrm{P}<0.05)$ morphometric indices. According to body and compactness indices averages also was verified that the animals tended for a more compact conformation. Males were higher than females in all measurements and weight. Correlations between all measures were high and positive. The studied animals show a longilinear conformation, tending to compact.

KEY WORDS: Correlation; Morphometry; Sheep; Weight.

\section{INTRODUCTION}

Standard development models are useful in evaluating the conformation. Apart from the weighing, body measures describe more completely an individual or population than conventional weighing and grading methods (Salako, 2006).

Araújo Filho et al. (2007) emphasized that the measures, morphometric indices and performance related characteristics should be considered on improving programs in order to establish the relationship between animal conformation and its function.

The relationship between some morphometric measurements or between them and live weight allows that some indices be estimated, which could be useful to assess the animals development and fitness, called zoometric indices. On its turn, these measures allow identification of morphometric characteristics that can be improved and which animals would be genetically superior (Felipe et al., 2005).
The northern region of the State of Rio de Janeiro, known as Norte Fluminense, is characterized by an extensive sheep breeding which is mostly composed by Santa Ines breed animals, who have obtained $112 \%$ increase in the last eleven years.

According to Afonso et al. (2009), the knowledge of the growth parameters for the Santa Ines is essential for this breed genetic improvement program formation. Linked to this, contributing to a better understanding of these animals' development as changes in production systems regarding the sheep nutrition and breeding areas.

In reference to the above, the aim of this work was to study the effects of the period of the year and year of the birth effects, sex and age on live weight, measurements and morphometric indices to calculate the correlations between the different measures and indices in Santa Ines offspring in the northern part of the State of Rio de Janeiro, Brazil

* Instituto de Zootecnia da Agência Paulista de Tecnologia dos Agronegócios, São Paulo, Brazil.

** Universidade Estadual do Norte Fluminense Darcy Ribeiro. Rio de Janeiro, Brazil.

*** Técnico em Agropecuária do Centro Paula Souza, São Paulo, Brazil,

***** Centro Universitário do Espírito Santo - UNESC, Espírito Santo, Brazil.

****** Instituto Federal do Espírito Santo, Espírito Santo, Brazil. 


\section{MATERIAL AND METHOD}

We analyzed 2,601 live weight observations and body measurements of Santa Ines sheep of both sexes, simple delivery, recorded during three years, belonging to a property located in São João da Barra city/Rio de Janeiro, South latitude geographic coordinates 21043'06", west longitude 41003 '59" and altitude of 5 meters above sea level.

The breeding system was extended in native pasture (Panicum repens), with water and mineral salt being offered "ad libitum". Food supplementation was based on bran supplemented with Pennissetum purpureum, just for lactating females. Weaning occurred at about 90 days. Although the property showed good facilities, it was identified that the food was defective due to the type of the sandy soil, native grasslands and warm weather most of the year. Matings were held in the field, females released in conjunction with breeding (proportion of approximately 1:100) all the year round, without any selection. In 2005 a known ancestry and new breeding was introduced in the herd.

The animals were weighed and measured every 15 days from birth until 12 months-old. The evaluated characteristics were body weight $(\mathrm{kg})$ and morphometric measurements: withers and rump height $(\mathrm{cm})$, body length $(\mathrm{cm})$ and thoracic perimeter $(\mathrm{cm})$. A mechanical scale was used for weighing. Body length measurements and thoracic perimeter were obtained using a tape measure, and height by a hipometer. The rump height $(\mathrm{RH})$ was defined to be the measure from sacrum anterior portion to the floor and the withers (WH) from withers to the floor. The thoracic perimeter (TP) has corresponded to the outer circumference of the chest cavity, near the armpits and the body length (BL) was obtained from the cranial point of the humerus greater tuberosity to the ischial tuberosity caudal point.

Morphometric indices were calculated as described by Costa Junior et al. (2006) and Araújo Filho et al.: body capacity 1 (BC1) corresponding to quotient between weight and body length and body capacity 2 (BC2) corresponding to quotient between weight and thoracic perimeter. We also calculated the body indices (BoI) described by McManus et al. (2008), Campelo et al. (2002), Casanova \& Miquel (2007) and Mernies et al. (2007), corresponding to the quotient between the body length and the thoracic perimeter x 100 . The body side indice (BoSI) was described by Casanova \& Miquel and Mernies et al. as the quotient between the withers height and the body length $x 100$. The anamorphosis indice (AnamI) had the quotient between the thoracic perimeter and the thoracic perimeter squared, the compactness indice (ComI), the quotient between weight and withers height $\mathrm{x}$
100 and body proportionality indice (BoPropI) had the quotient between the compactness indice and the body indice x 100, described by Casanova \& Miquel.

According to McManus et al. and Campelo et al., when the body indice is greater than 0.90 it indicates longilineal animals (long), from 0.85 to 0.90 , mediolign (medium), and compact when less than 0.85 (short).

Starting on the birth date and weighing, the animal's age was calculated from the birth to 365 days. Ages were used to categorize the age groups 0-15 - 30 - 60-90 - 120$150-180-210-240-270$ - 365 days.

Initially, the data consistency was performed in order to eliminate observations that showed identifiable typing, measurement and / or information errors.

The descriptive statistical analysis was performed in order to know the means, standard deviations and coefficients of variation. Preliminary variance analysis was performed to verify the period of the year and year of the birth effects, sex and age of the lambs and the simple and triple interactions of fixed effects on measures and between morphometric indices and weight (PROC GLM, SAS Institute Inc. SAS/STAT ${ }^{\circledR}$ $9.2,2008)$. As there were no significant differences due to period of the year, the model was used for the final analysis:

$\mathrm{Y}_{\mathrm{ijkl}}=+\mathrm{AN}_{\mathrm{i}}+\mathrm{SX}_{\mathrm{j}}+\mathrm{ID}_{\mathrm{k}}+\mathrm{INT}_{(\mathrm{ijk})}+\mathrm{e}_{\mathrm{ijkk}}$

where:

$\mathrm{Y}_{\mathrm{ijk}}=$ dependent variable (Morphometric Indices);

$\mu=$ general average

$\mathrm{AN}_{\mathrm{i}}=$ fixed effect from $\mathrm{i}^{\text {esimo }}$ year of birth;

$S X_{\mathrm{j}}=$ fixed effect from $\mathrm{j}^{\text {ssimo }}$ animal sex;

$\mathrm{ID}_{\mathrm{k}}=$ fixed effect from $\mathrm{k}^{\text {ésimo }}$ animal age;

$\mathrm{INT}_{(\mathrm{ijk})}=$ simple and triple interactions between the fixed effects.

$\mathrm{e}_{\mathrm{ijkl}}=$ random error associated with each observation $(\mathrm{N} \sim 0.1)$.

Means were compared by SNK test and the simple correlations between the morphometric indices were calculated using the PROC CORR (SAS, 2008).

\section{RESULTS AND DISCUSSION}

Several studies of morphometric indices are performed worldwide. However, the vast majority is directly related to the breed characterization and conformation (Otoikhian et al., 2008) with Ouda sheep; Gusmão Filho et al. (2009), with Santa Ines; Dzib et al. (2011), with 


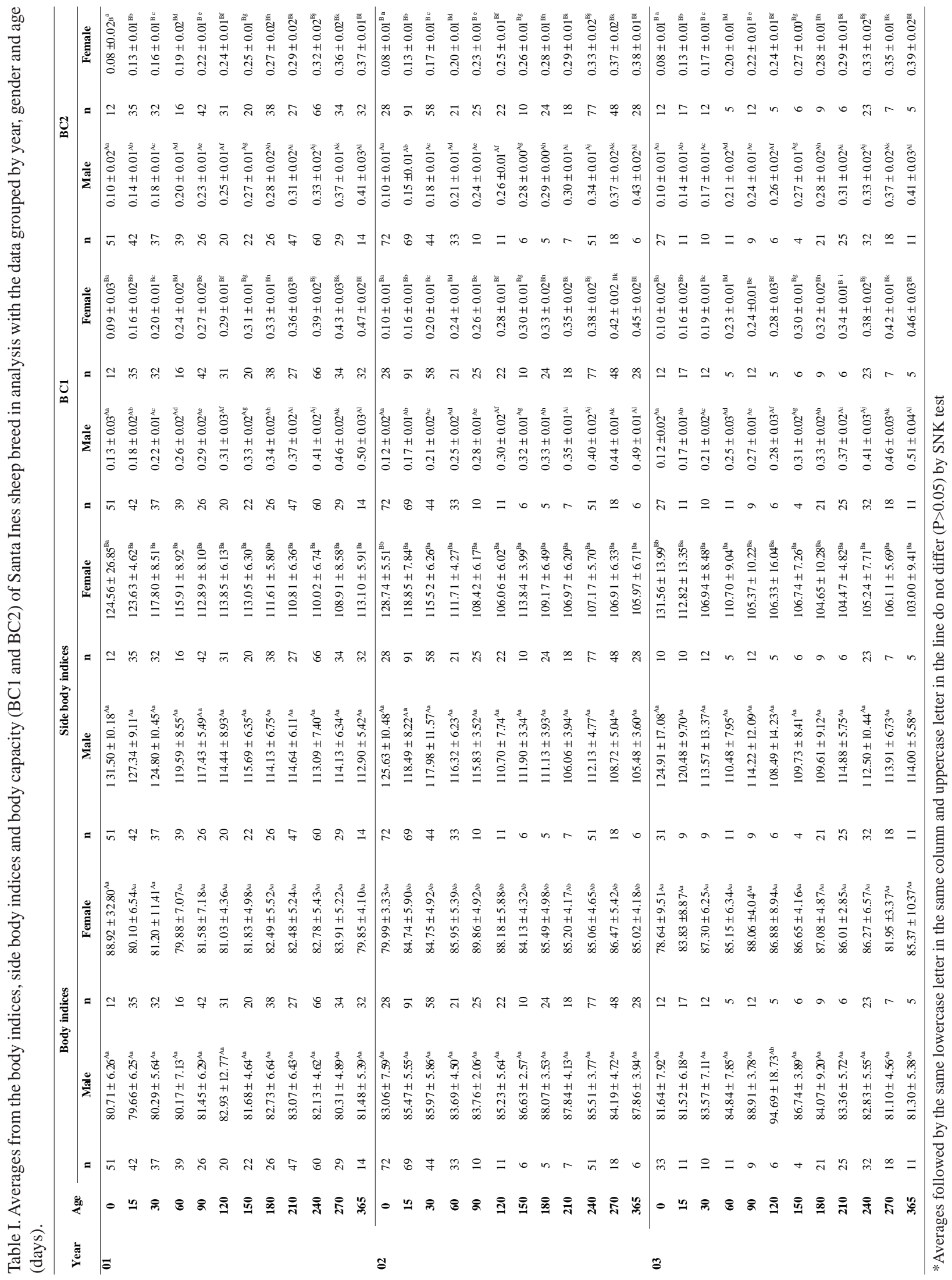


Blackbelly breed. Nevertheless, some authors have studied the morphological indices application in type and functionality of sheep assessing (Bravo \& Sepúlveda, 2010; Latorre et al., 2011).

In this work, the year of birth, sex, animal age and triple interaction between these effects have influenced $(\mathrm{P}<0.05)$ the studied features in growing sheep. Regarding the effect of the year, no significant difference for body weight between the years studied was observed, possibly due to the same kind of nutritional management applied throughout all the period.

Quesada et al. (2002) observed the effect of year on the live weight of Santa Ines sheep in extensive breeding in the Federal District, Brazil. Felipe et al., pointed out that the order of maturation of body components is: nerves, skeleton, muscle and fat. Thus, changes in environmental and nutritional conditions primarily affect the muscles and the fat, in that order. These authors have concluded that, under conditions of food scarcity, morphometric measurements, thoracic perimeter, body length and rump and withers height are more reliable for assessing the growth because are related to skeletal development.

The average results of the body capacity 1 (BC1) and the body capacity 2 (BC2) and body and side body indices according to year, sex and age are shown in Table I.

Considering the year effect, a significant difference $(\mathrm{P}<0.05)$ has been found for $\mathrm{BC} 1$ between the years. A decrease in averages was noted due to the differences in body length of the animals which have increased, since no difference on the weights were shown during the studied period. The same occurred with BC2. It can be possibly clarified by the average decreasing of animal's thoracic perimeters that occurred during the studied period. However, in 2006 the $\mathrm{BC} 2$ values in males decreased or remained, due to the average thoracic perimeter increase found this year.

Considering the body indice (BoI) and body side indice $(\mathrm{BoSI})$, there were significant differences $(\mathrm{P}<0.05)$ because of the year (Table I). According to the average values of the body indice in first year, the animals fall into the compact conformation and, in the second year, would be mediolign. In the third year, the males showed compact conformation and females mediolign, according to the McManus et al. and Campelo et al. classification. This difference on the conformation could be, again, due to introducing of a player with greater aptitude for cutting. The body conformation (BoI and BoSI) can be defined by the relationship between height and length of the thoracic perimeter. Thus, the longilineal animals, known as "waders", would be those highs and long and compacts, called 'compact', those low and short, which is the predominant and desirable conformation for animals with ability to beef breed.

According to the Álvarez et al., (2000a, 2000b), Casanova \& Miquel and Mernies et al., classification for the body side indice, the studied animals would be seen against the longilineal conformation, i.e. this study animals would be classified as high and long, not approaching the ideal shape to be raised for slaughter.

However, there was a reduction of this indice values in function of increase in body length averages and the decrease in withers height averages over the years, tending the animals to a less longilineal conformation, in other words, becomes longer and low.

Considering the sex effect, males also showed higher averages for $\mathrm{BC} 1$ and $\mathrm{BC} 2$ showing to be heavier, long and with greatest thoracic depth, a fact also observed by Costa Junior et al. According to these authors classification, the animals of the present study would look a longilineal conformation.

The superiority of the male body side indice was verified, disagreeing with the results observed by Álvarez et al. (2000a, 2000b) and Casanova \& Miquel.

Regarding the age effect it is observed that when the age increases, the $\mathrm{BC} 1$ and $\mathrm{BC} 2$ values also increase simultaneously with this related-indices measures increase.

Regarding the age factor alone, the same observed by Costa Junior et al., has been verified. The increase of the $\mathrm{BC} 2$ values was lower than that observed for $\mathrm{BC} 1$, i.e., weight and thoracic perimeter tend to a simultaneous increase of its average, which does not occur with body length that tends to decrease with increasing age. There was no proportionality to the $\mathrm{BC} 1$ and $\mathrm{BC} 2$ values, i.e. there was variation in bone growth rate and muscle and body fat deposition of animals in this study.

It has been observed that, from birth to 180-days of age and from 210 days of age, there was a greater variation in the $\mathrm{BC} 1$ and $\mathrm{BC} 2$ values, mainly $\mathrm{BC} 1$, probably because in the initial age the bone growth and weight gain rates are largest and from 210 days of age the animals can be meet the skeletal maturation where the weight increase was higher than the increase of body length and thoracic perimeter measures. 
The lateral body indice decreases linearly as the age increases, due to the animal's growth reducing in height and length, as observed by Campelo et al.

With respect to compactness indice (ComI) and proportionality indice (BoPropI) there was a significant difference $(\mathrm{P}<0.05)$ between the years (Table II). An increase of the ComI averages due to over the years the weight averages were kept and the withers height was decreased, making the animals more compact.

Through the years, higher rates of compactness and body indices were verified, but with greater magnitude increase for the body indice.

On having the body and compactness indices as variable, the proportionality indices refers to the animal's conformation, i.e. as much as the animals are compact or longilineals. In this study, according to body and compactness indices averages also was verified that the animals tended for a more compact conformation (Table II).

Regarding the sex effect, there was difference $(\mathrm{P}<0.05)$ for the compactness, proportionality and anamorphosis indices. Males had higher averages for these indices, which is consistent with the findings of Casanova \& Miquel.

Regarding age, it was verified that as there is an increase of age, the animals become more compact less high and more compact due to a higher deposition of muscle and fat and to lower bone growth. However, for this indice, the animals in this study can still be classified as longilineal, as also demonstrated by the lateral body indice.

Because of considering the thoracic perimeter averages on its calculation, the indice anamorphic (AnamI) showed same averages and the same influences of the year, sex and age effects of this measure (Table II), as also observed by Casanova \& Miquel who reported superior average for this indice than this current work, however, these authors have worked with adult animals of both sexes.

The correlations between weight and morphometric measurements and the correlations between all measures were high and positives ( $\mathrm{r}=0.91$ to 0.97$)$, and these results are consistent with several studies.

The highest correlations were found between withers height and hip height $(\mathrm{r}=0.97)$, in agreement with the finding by Campelo et al., followed by live weight and thoracic perimeter $(\mathrm{r}=0.94)$.
The high positive correlation between $\mathrm{BC} 1$ and $\mathrm{BC} 2$ $(\mathrm{r}=0.98)$ and morphometric measurements ( $\mathrm{r}=0.88$ to 0.94$)$ and weight $(\mathrm{r}=0.98)$ are coming out of the high also positive correlation between all measurements and between these and the weight which are used in both indices calculation.

More studies should be conducted in order to determine which would be the best indices to be used as selection criteria to increase the animal production systems efficiency and facilitate the data collection directly from the fields. This work suggests the indices $\mathrm{BC} 1, \mathrm{BC} 2$, BoSI would be sufficient to evaluate the animals conformation.

\section{CONCLUSIONS}

Under field conditions, the use of many morphometric measurements to evaluate the animals and predict the live weight is not necessary, as there are high positive correlations between the studied measures. These measurements are useful to obtain indices in order to evaluate the conformation to be applied in screening programs. However, variations due to observed effects in this study should be considered even in creations subjected to the same type of management.

Inappropriate nutritional management has probably influenced animal growth, and the genetically superior breeding introduction in the herd may also have influenced the conformation, making them longer and shorter.

DA COSTA, R. L. D.; QUIRINO, C. R.; ALFONSO, V. A. C.; PACHECO, A.; BELTRAME, R. T.; MADELLA-OLIVEIRA, A. F.; COSTA, A. M. \& DA SILVA, R. M. C. Índices morfométricos en ovejas Santa Inés. Int. J. Morphol., 32(4):1370-1376, 2014.

RESUMEN: Los efectos de la estación, año de nacimiento, edad y sexo sobre índices morfométricos como: capacidad del cuerpo, índice corporal, índice del cuerpo, índice de anamorfosis, índice de compacidad y índice de proporcionalidad corporal fueron evaluados y fueran estimadas las correlaciones entre ellos. Se utilizaron ovejas Santa Inés desde el nacimiento hasta los 12 meses de edad, criadas en el norte del Estado de Río de Janeiro. Las evaluaciones fueron realizadas durante un período de tres años, totalizando 2.601 observaciones. El año de nacimiento, el sexo, la edad del animal y la interacción entre ellos tuvo efectos $(\mathrm{P}<0,05)$ sobre los índices estudiados. A partir de las medidas corporales y de los niveles de compacidad se observó que los animales tienden a presentar conformación más compacta. Las correlaciones entre las medidas fueron altas y positivas. Los animales estudiados muestran una conformación longilínea, tendiendo a compacto.

PALABRAS CLAVE: Correlación; Morfometría; Ovejas; Peso. 


\section{REFERENCES}

Afonso, V. A. C.; Quirino, C. R.; Costa, R. L. D. \& Silva, R. M. C. Aplicação de modelos não-lineares no ajuste de curvas de crescimento em fêmeas ovinas (Ovis aries) da raça Santa Inês criadas na região Norte Fluminense- RJ. Bol. Ind. Anim., 66(2):115-20, 2009.

Álvarez, S.; Fresno, M.; Capote, J.; Delgado, J. V. \& Barba, C. Estudio para la caracterizacion de la raza ovina Palmera. Arch. Zootec., 49(185-186):217-22, 2000a.

Álvarez, S.; Fresno, M.; Capote, J.; Delgado, J. V. \& Barba, C. Estudio para la caracterización de la raza ovina Canaria. Arch. Zootec., 49(185-186):209-15, 2000b.

Araújo Filho, J. T.; Costa, R. G.; Fraga, A. B.; Sousa, W. H.; Gonzaga Neto, S.; Batista, A. S. M. \& Cunha, M. G. G. Efeito de dieta e genótipo sobre medidas morfométricas e não constituintes da carcaça de cordeiros deslanados terminados em confinamento. Rev. Bras. Saúde Prod. Anim., 8(4):394404, 2007.

Bravo, S. \& Sepulveda, N. Zoometric Indices in Araucanas Creole Ewes. Int. J. Morphol., 28(2):489-95, 2010.

Campelo, J. E. G.; Oliveira, M. E. \& Lopes, J. B. Morfometria e correlações entre medidas corporais externas de ovinos da raça Santa Inês. In: Reunião Anual da Sociedade Brasileira de Zootecnia, 39, Recife. Anais. Recife, SBZ, 2002.

Casanova, P. I. \& Miquel, P. Análisis biométrico y funcional de la raza ovina Aranesa, REDVET Rev. Electrón. Vet., 8(1):1-8, 2007.

Costa Júnior, G. S.; Campelo, J. E. G.; Azevêdo, D. M. M. R.; Martins Filho, R.; Cavalcante, R. R.; Lopes, J. B. \& Oliveira, M. E. Caracterização morfométrica de ovinos da raça Santa Inês criados nas microrregiões de Teresina e Campo Maior. Rev. Bras. Zootec., 35(6):2260-7, 2006.

Dzib, C. A.; Ortiz De Montellano, A. \& Torres-Hernández, G. Variabilidad morfoestructural de ovinos Blackbelly en Campeche, México. Arch. Zootec., 60(232):1291-301, 2011.

Felipe, D. C. A.; Ana, O. M.; Glafiro, T. H. \& Everardo, A. N. Conformaciòn corporal de ovinos Blackbelly em rebaños comerciales del município de Campeche. In: Memórias del Seminário de Producción de Ovinos en el Trópico, 4, México D. F., 2005. pp.46-51.

Gusmão Filho, J. D.; Teodoro, S. M.; Chaves, M. A. \& Oliveira, S. S. Análise fatorial de medidas morfométricas em ovinos tipo Santa Ines. Arch. Zootec., 58(222):289-92, 2009.

Latorre, E.; Uribe, H.; Martinez, M. E.; Calderón, C. \& de la Barra, R. Morphology differentiation and structural functionality of ewes due to incomplete crossbreeding. Int. J. Morphol., 29(3):954-9, 2011.

Mcmanus, C. M.; Santos, S. A.; da Silva, J. A.; Louvandini, H.; Abreu, U. G. P.; Sereno, J. R. B. \& Mariante, A. S. Body Indices for the pantaneiro horse. Braz. J. Vet. Res. Anim. Sci., 45(5):362-70, 2008.

Mernies, B. ; Macedo, F. ; Filonenko, Y. \& Fernández, G. Índices zoométricos en uma muestra de ovejas criollas uruguayas. Arch. Zootec., 56(Sup. 1):473-8, 2007.

Otoikhian, C. S. O.; Otoikhian, A. M.; Akporhuarho, O. P. \& Isidahomen, C. Correlation of body weight and some body measurement parameters in Ouda sheep under extensive management system. Afr. J. Gen. Agric., 4(3):129-33, 2008.

Quesada, M.; Mc Manus, C. \& Couto, F.A.A. Efeitos genéticos e fenotípicos sobre características de produção e reprodução de ovinos deslanados no Distrito Federal. Rev. Bras. Zootec., 31(1):342-9, 2002.

SAS Institute Inc. SAS/STAT® 9.2 User's Guide. Cary, SAS Institute Inc., 2008. Disponible en: https://support.sas.com/ documentation/cdl/en/statugvariance/61753/PDF/default/ statugvariance.pdf

Salako, A.E. Principal component factor analysis of the morphostructure of immature Uda sheep. Int. J. Morphol., 24(4):571-4, 2006.

Correspondence to:

Ricardo Lopes Dias da Costa

Instituto de Zootecnia da Agência Paulista de Tecnologia dos Agronegócios

Rua Heitor Penteado, 56, Nova Odessa

São Paulo, 13460-000

BRAZIL

Email: rldcosta@iz.sp.gov.br

Received: 07-08-2014

Accepted: 27-09-2014 